\title{
Gene expression profiling of individual bovine nuclear transfer blastocysts
}

\author{
Joanna Somers ${ }^{1,2}$, Craig Smith ${ }^{1}$, Martyn Donnison ${ }^{1}$, David N Wells ${ }^{1}$, Harold Henderson ${ }^{1}$, \\ Lance McLeay ${ }^{2}$ and P L Pfeffer ${ }^{1}$ \\ ${ }^{1}$ AgResearch Ruakura, Hamilton, New Zealand and ${ }^{2}$ University of Waikato, Department of Biological Sciences, \\ Hamilton, New Zealand \\ Correspondence should be addressed to P L Pfeffer; Email: peter.pfeffer@agresearch.co.nz
}

\begin{abstract}
During somatic cell nuclear transfer the gene expression profile of the donor cell has to be changed or reprogrammed extensively to reflect that of a normal embryo. In this study we focused on the switching on of embryonic genes by screening with a microarray consisting of 5000 independent cDNA isolates derived from a bovine blastocyst library which we constructed for this purpose. Expression profiling was performed using linearly amplified RNA from individual day 7 nuclear transfer (NT) and genetically half-identical in vitro produced (IVP) blastocysts. We identified 92 genes expressed at lower levels in NT embryos whereas transcripts of 43 genes were more abundant in NT embryos $(P \leq \mathbf{0 . 0 5}, \geq 1.5$-fold change). A range of functional categories was represented among the identified genes, with a preponderance of constitutively expressed genes required for the maintenance of basal cellular function. Using a stringent quantitative SYBR-green real time RT-PCR based approach we found, when comparing the means of the expression levels of a larger set of individual embryos, that differences were small ( $<2$-fold) and only significant for two of the seven analysed genes (KRT18, SLC16A1). Notably, examination of transcript levels of a single gene in individual embryos could not distinguish an NT from a control embryo. This unpredictability of individual gene expression on a global background of multiple gene expression changes argues for a predominantly stochastic nature of reprogramming errors.

Reproduction (2006) 131 1073-1084
\end{abstract}

\section{Introduction}

Mammalian nuclear transfer (NT) cloning has produced live, viable offspring in many species, yet cloning efficiencies are always very low, with generally less than $4 \%$ of reconstructs reaching term (Wilmut et al. 2002). Early gestational losses of NTembryos are often associated with aberrant placental development in livestock and mice (Hill et al. 2000, De Sousa et al. 2001, Ogura et al. 2002). Anomalies in foetal and perinatal stage cloned calves and lambs are heterogeneous, including excessive birth weight (large offspring syndrome), defects in the gastrointestinal, cardiopulmonary, hepatic and renal systems as well as skeletal malformations (Wells et al. 1997, Zakhartchenko etal. 1999, 2001, Lanza etal. 2001, Gibbons et al. 2002, Pace et al. 2002, Rhind et al. 2003). Furthermore, survival beyond term is also affected with annual mortalities of $8 \%$ reported in cattle (Wells et al. 2004) and early death in mice (Ogonuki et al. 2002).

The primary cause of defects in clones is postulated to be epigenetic, based on the observation that abnormalities of clones are not transmitted to subsequent generations (Shimozawa et al. 2002, Tamashiro et al. 2002, Wells et al. 2004). For the survival of a NT reconstructed embryo, the epigenetic memory of the donor cell nucleus has to be erased and the chromatin remodeled into an embryo-equivalent state in a reprogramming process that leads to the correct initiation of the embryonic gene expression programme. Such chromatin remodelling in clones is often incomplete as demonstrated by aberrant DNA methylation patterns in bovine NT embryos (Bourc'his et al. 2001, Dean et al. 2001, Kang et al. 2001, 2002). Likewise, histone lysine methylation and acetylation changes in bovine clones showed disparity relative to control embryos (Santos et al. 2003). Observations that NT mouse embryos, in contrast to control embryos, developed more efficiently in donor cell culture medium than in embryo culture medium, implies that donor cell transcription may not have ceased after transfer (Gao et al. 2003). Improved viability was observed when using embryonic stem (ES) as opposed to somatic cells 
(Hochedlinger \& Jaenisch, 2002). ES cells more closely resemble embryos in terms of their gene expression profile than do differentiated cells and hence less nuclear reprogramming may be required upon using ES cells for NT. Thus the superior NT efficiencies when using ES cells suggests that correct embryonic genome activation constitutes a major hurdle during somatic nuclear transfer.

Gene expression studies in nuclear transfer embryos have been published for several species. In mice, pluripotency genes involved in early development have been reported to be misregulated in cloned embryos (Boiani et al. 2002, Bortvin et al. 2003). The expression of cattle NT blastocysts has been previously studied in an attempt to identify marker genes that would predict clone developmental competence (Daniels et al. 2000, Donnison \& Pfeffer 2004). Many of the previous studies measured the expression of only a small number of genes by semi-quantitative RT-PCR (Daniels et al. 2000, 2001, Wrenzycki et al. 2001, Park et al. 2003). Detailed quantitative analyses of individual blastocysts has revealed a large degree of embryo to embryo variation and only subtle changes in expression levels (Camargo et al. 2005). These studies, however, offer only a limited picture of the gene transcription changes occurring after nuclear transfer. In order to obtain a more complete picture of the accuracy and extent of nuclear reprogramming, a global method is required. One group has recently used such an approach, creating a microarray from cDNA derived from cultured genital ridge cells, and identified 18 genes as significantly differentially expressed between NT and in vitro produced (IVP) embryos (Pfister-Genskow et al. 2005).

We have here addressed this issue further, focusing on gene activation in NT embryos. To this end we have constructed a novel bovine blastocyst cDNA library and synthesised a 5000 feature blastocyst-stage microarray, allowing us to compare embryonic gene expression in individual NT blastocysts with that of genetically halfidentical IVP blastocysts. Genes identified from the microarray as differentially expressed were analysed further by quantitative real time RT-PCR. We interpret our results in terms of a stochastic model for reprogramming.

\section{Materials and Methods \\ IVP and NT embryo production}

Abattoir recovered ovaries were aspirated, with oocytes matured in vitro and used to generate either zona-free IVP or NT blastocysts. Generation of IVP embryos by in vitro fertilisation (IVF; using sperm from bull AESF 1) was as previously described (Thompson et al. 2000) with the exceptions of zona removal after IVF and single embryo culture. Bovine NT, using cultured skin fibroblasts recovered from bull AESF 1 and embryo culturing of both the IVP and NT embryos using a synthetic oviduct fluid system, with embryos cultured singly has been previously described (Oback et al. 2003). Grading and staging of development according to published guidelines (Robertson \& Nelson 1998) was performed by only one of us (D.N.W.). Briefly, grade 1 embryos were symmetrical with well-defined and uniform blastomeres. Grade 2 embryos had moderate irregularities in the shape or size of the inner cell mass or similar irregularities in the size, colour or density of the individual blastomeres. Single embryos were washed in PBS and transferred in a minimal volume into individual tubes. These were immediately flash frozen in liquid nitrogen and kept at $-80{ }^{\circ} \mathrm{C}$ until RNA extraction. A reference standard was created from a pool of 200 zona-intact day 7 IVP blastocysts.

\section{RNA isolation and amplification}

For the amplification procedure, RNA was isolated from individual embryos and the reference standard pool using the RNAqueous micro kit (Ambion, Austin, TX). The manufacturer's protocol was followed with the following modifications. To each thawed sample $200 \mathrm{ng}$ of poly-deoxy-inosinic-deoxy-cytidylic acid (poly[d(I-C)]; Roche, Mannheim, Germany) was added. The elution volume of $40 \mu \mathrm{l}$ was reduced to $10 \mu \mathrm{l}$ with a SVC100H speedvac concentrator and the DNase I treatment step was omitted. Non-stick microfuge tubes were used (Neptune \#3435.S3, Raylab, Auckland, New Zealand).

Individual blastocyst samples were subjected to two rounds of linear amplification using the Arcturus RiboAmp RNA amplification kit (Arcturus, Gene Works, Auckland, New Zealand) using a modified version $\mathrm{A}$. The modifications included using the centrifuge conditions described in version $\mathrm{C}$ of the manufacturer's protocol and a first round in vitro transcription length of $5 \mathrm{~h}$ at $42{ }^{\circ} \mathrm{C}$ and $4{ }^{\circ} \mathrm{C}$ overnight. For the second round of in vitro transcription, reagent volumes were doubled and samples incubated for $6 \mathrm{~h}$ at $42{ }^{\circ} \mathrm{C}$ then $4{ }^{\circ} \mathrm{C}$ overnight. Sample yields and the integrity of the amplified antisense RNA (aRNA) was examined spectrophotometrically and by gel electrophoresis. Yields were as follows (in $\mu$ g): IVP embryos35, 35, 53 and 71; NT embryos-67, 81, 33, 34 and 25. aRNA was stored at $-80^{\circ} \mathrm{C}$.

For the reference standard, the first round of linear amplification was performed with the Arcturus kit and the yield determined by spectrophotometer. Aliquots (280 ng) were made to which $200 \mathrm{ng}$ poly[d(I-C)] was added. For the second linear amplifications a modified version of the protocol by Wang and colleagues was used (Wang et al. 2000). Modifications included the use of Microcon YM-100 columns (Millipore, North Ryde, Australia) for double-stranded DNA clean-up, an incubation period of $5 \mathrm{~h}$ at $37^{\circ} \mathrm{C}$ and $4{ }^{\circ} \mathrm{C}$ overnight 
for the in vitro transcription reaction and the use of the RNAqueous micro kit (Ambion) for aRNA clean-up. All second round amplifications of the standard reference were pooled and the yield quantified with a spectrophotometer. The standard reference aRNA was stored at $-80^{\circ} \mathrm{C}$.

\section{cDNA blastocyst library construction}

Total RNA was obtained from 640 day 7 and 8 bovine IVP blastocysts using the Trizol procedure (Invitrogen, Auckland, New Zealand). PolyA ${ }^{+}$RNA was isolated using the MicroPolyA Purist kit (Ambion). PolyA ${ }^{+}$RNA (160 ng was reverse-transcribed following the SMART cDNA protocol (PT3000-1, 2001; Clontech, BD Biosciences, Auckland, New Zealand), but using Superscriptll (Invitrogen) for reverse transcription. Protocol PT3000-1 was followed using 24 cycles for LD-PCR amplification. cDNA ligated to $\lambda$ TriplEx2 vector was packaged using MaxPlax $\lambda$ Packaging Extract (Epicentre, Madison, WI) and titered using E. coli XL-1 blue cells according to standard protocols.

\section{Microarray generation}

The primary $\lambda$ pTriplEx2 library was plated at low density on $15 \mathrm{~cm}$ plates containing IPTG and X-Gal to allow for individual recombinant white plaques to be picked. Five thousand plaques were randomly selected and each added to $50 \mu \mathrm{l} \lambda$-dilution buffer $(100 \mathrm{mM}$ $\mathrm{NaCl}, 10 \mathrm{mM} \mathrm{MgSO}_{4}, 35 \mathrm{mM}$ Tris- $\mathrm{HCl}$ pH 7.5, 0.01\% gelatine) and $2 \mu \mathrm{l}$ of chloroform in 96-well plates, before storage at $4{ }^{\circ} \mathrm{C}$. The insert of each phage was amplified in a $50 \mu \mathrm{l}$ PCR reaction containing $2 \mu \mathrm{l}$ phage, $0.25 \mu \mathrm{l}$ each of primers $\lambda \operatorname{TriplE}^{\prime} 5^{\prime}$ (5'-CTCGGGAAGCGCGCCATTGTGTTGGT-3') and 3' (5'-ATACGACTCACTATAGGGCGAATTGGCC-3'; Clontech), $5 \mu \mathrm{l} 10 \times \mathrm{PCR}$ buffer (Roche), $1 \mu \mathrm{l} 10 \mathrm{mM}$ dNTP and $0.2 \mu \mathrm{l} 5$ Units/ $\mu$ l Taq DNA polymerase (Roche). Cycling conditions were $94{ }^{\circ} \mathrm{C}$ for $5 \mathrm{~min}$, followed by 40 cycles of $94{ }^{\circ} \mathrm{C}$ for $15 \mathrm{~s}, 58{ }^{\circ} \mathrm{C}$ for $30 \mathrm{~s}$ and $72{ }^{\circ} \mathrm{C}$ for $2 \mathrm{~min}$, with a final extension of $72{ }^{\circ} \mathrm{C}$ for $7 \mathrm{~min}$. Two microlitres were used for gel electrophoresis to examine the amplified inserts.

Preparation of microarray slides, preparation of PCR amplified DNA for microarray printing and microarray printing was according to published protocol (DiezTascón et al. 2005). The microarrays were printed with an ESI array robot (Toronto, Canada) using a 32 pin head. Each pin head printed a block of 180 spots. We included 243 blank spots (no DNA) per array. Array details can be accessed at the ArrayExpress database (http://www.ebi. ac.uk/arrayexpress/) under A-MEXP-312.

\section{cDNA labelling and microarray hybridisation}

Two micrograms of amplified aRNA from the individual blastocyst samples and aliquots of the reference sample were converted into cDNA and aminoallyl-labelled using the Invitrogen Superscript cDNA Labelling System according to the manufacturer's protocol. Single embryo samples were labelled with Cyanin (Cy) 5 dye and the standard reference sample with Cy3 (Amersham, Auckland, New Zealand). After the final elution the two samples to be compared on each microarray were combined, $10 \mu \mathrm{l} 3 \mathrm{M}(\mathrm{pH}$ 5.3) sodium acetate and $2 \mu \mathrm{l}$ $20 \mathrm{mg} / \mathrm{ml}$ glycogen (Roche) added before ethanol precipitation and resuspension in $10 \mu \mathrm{l}$ DEPC-water. Microarray pre-hybridisation, hybridisation and posthybridisation conditions were as previously described (Diez-Tascón et al. 2005). Dye-reversal hybridisation where the standard reference was labelled with either Cy3 or Cy5 and the two samples hybridised against one slide gave a correlation coefficient of 0.995 .

\section{Microarray analysis}

Microarray slides were scanned at a resolution of $10 \mu \mathrm{m}$ by a GenePix 4000A microarray scanner (Axon Molecular Devices, Sunnyvale CA). Cy 5 and Cy 3 fluorescence was measured at a 16 bit pixel resolution. Tagged image files were converted into data files using GenePix Pro 4.1 software (Axon). GenePix analysis included automatic as well as manual flagging of bad spots. Microarray data was manipulated and displayed using Data Desk 6.1 (Data Description, Ithaca, NY) and deposited in the public ArrayExpress database under accession number E-MEXP-556. Graphical displays were also generated using S-PLUS 6.1 (Insightful Corporation, Seattle, WA) and Microsoft Excel. Statistical analysis was conducted using a spatial mixed model (Baird et al. 2004) with GenStat software (VSN International, Oxford, UK). Differential expression between the mean of the IVP and NT blastocyst samples was determined using a t-test, with an arbitrary cut-off of 1.5 -fold change and a 5\% significance level. Reproducibility in hybridisation was monitored by including 384 features spotted in duplicate at different positions within each microarray slide. Comparison of the log intensity ratios across this data set revealed an average correlation ration of 0.83 .

\section{Sequencing of significantly differentially expressed probes}

Inserts of interest were PCR amplified as described above and sequenced (Eck et al. 2004) from the $5^{\prime}$ direction using the TriplEx5'LD primer (\#9107-1; Clontech) before separation on a Prism 3100 DNA sequencer (Applied Biosystems). Sequence information was analysed using BLASTN searches of public databases. An expected value of $\mathrm{e}^{-10}$ or less was considered to be a significant match. 


\section{Total RNA isolation, DNase treatment and reverse transcription}

Single day 7 zona-free IVP or NT blastocysts were placed in $100 \mu \mathrm{l}$ of Trizol (Invitrogen, Auckland, New Zealand) to which 5 pg rabbit $\alpha$-globin mRNA (Sigma, Sydney, Australia) and 800 ng of MS2 RNA (Roche, Auckland, New Zealand) were added. Samples were extracted with $20 \mu \mathrm{l}$ of chloroform followed by the addition of $10 \mu \mathrm{g}$ linear acrylamide (Ambion, Austin, Texas) and $65 \mu \mathrm{l}$ of cold isoproanol. After $10 \mathrm{~min}$ at room temperature, samples were centrifuged at $14000 \mathrm{rpm}(16000 \mathrm{~g})$ for 30 min, washed with $150 \mu \mathrm{l} 70 \%$ ethanol and air-dried. After resuspension in $7 \mu \mathrm{l}$ DEPC-treated water, $2 \mu \mathrm{l} 1 \mathrm{U} / \mu \mathrm{l}$ RNase-free DNase1 (Invitrogen, Auckland, NZ) and $1 \mu \mathrm{l}$ of $10 \times$ DNase I buffer was added and samples incubated for $1 \mathrm{~h}$ at $37^{\circ} \mathrm{C}$. Samples were precipitated with $1.5 \mu \mathrm{l} 3 \mathrm{M}$ sodium acetate $(\mathrm{pH} 5.5)$ and $45 \mu \mathrm{l} 100 \%$ ethanol, washed in $70 \%$ ethanol and resuspended in $12 \mu \mathrm{l}$ DEPC-treated water.

To each sample $1 \mu \mathrm{l} 10 \mathrm{mM}$ dNTP and $1 \mu \mathrm{l} 10 \mathrm{mM}$ oligo $\mathrm{dT}_{14} \mathrm{VN}$ anchored primer (Invitrogen) were added before incubation at $65^{\circ} \mathrm{C}$ for $5 \mathrm{~min}$. Four microlitres $5 \times$ first strand buffer (Invitrogen), $1 \mu \mathrm{l} 40 \mathrm{U} / \mu \mathrm{l}$ Protector RNase inhibitor (Roche), $1 \mu \mathrm{l} 200 \mathrm{U} / \mu \mathrm{l}$ Superscript III (Invitrogen) were added and the samples incubated at $50{ }^{\circ} \mathrm{C}$ for $60 \mathrm{~min}$, then $70{ }^{\circ} \mathrm{C}$ for $15 \mathrm{~min}$. A reverse transcription negative (RT-) control was included. This was followed by the addition of $0.5 \mu \mathrm{l} 2 \mathrm{U} / \mu \mathrm{l}$ RNAse $\mathrm{H}$ (Invitrogen) for $30 \mathrm{~min}$ at $37^{\circ} \mathrm{C}$. After the addition of $2 \mu \mathrm{l}$ sodium actetate $(\mathrm{pH}$ 5.5) samples were passed through Qiaquick mini elute columns (Qiagen, Auckland, New Zealand) and resuspended in $40 \mu \mathrm{l}$ of TE buffer in non-stick $0.65 \mathrm{ml}$ tubes (Neptune \#3435.S3, Raylab, Auckland, New Zealand).

\section{Real time PCR analysis}

Seven of the genes identified by the microarray as differentially expressed-cytochrome c oxidase I; keratin 18 (KRT18); myosin, light peptide 6, alkali, smooth muscle and non-muscle (MYL6); ribosomal protein L21 (RPL21); solute carrier family 16 , member $\mathrm{A} 1$ (SLC16A1); $\beta$-tubulin isoform 5(TUBB); and tyrosine 5-monooxygenase/tryptophan 5-monooxygenase activation protein, theta isoform ( $Y W H A Q)$-were selected for quantitative expression analysis by SYBR-green real time PCR. In addition, glyceraldehyde-3-phospate dehydrogenase (GAPDH) and keratin 8 (KRT8) were examined. Primers (Table 1) were designed using GCG's Prime (Accelrys, San Diego, CA) and, where possible, were selected to cover putative intron sequences as determined by comparison to the homologous human gene loci.

Real-time PCR was performed on a Roche LightCycler 2 instrument using $10 \mu \mathrm{l}$ reactions containing $2 \mu \mathrm{l}$ of
Table 1 Primers used for quantitative real time PCR analysis.

\begin{tabular}{|c|c|c|c|c|}
\hline Gene & $\begin{array}{l}\text { Primer sequence }\left(5^{\prime} \text { to } 3^{\prime} \text {; }\right. \\
\text { forward, reverse) }\end{array}$ & $\begin{array}{l}\text { Size } \\
\text { (bp) }\end{array}$ & $\begin{array}{c}\text { Intro- } \\
\text { ns }\end{array}$ & $\begin{array}{r}\text { PCR } \\
\text { effic }^{2}\end{array}$ \\
\hline GAPDH & $\begin{array}{l}\text { CTGTTGAAGTCGCAGGAGAC, } \\
\text { TATCATCCСTGCTTCTACTG }\end{array}$ & 247 & 0 & 1.9 \\
\hline MYL6 & $\begin{array}{l}\text { AAGAACAAGGACCAGGGCA, } \\
\text { GCAGACATCATCCAAGAAAGAG }\end{array}$ & 391 & 3 & 1.9 \\
\hline RPL21 & $\begin{array}{l}\text { GATGACCAACACAAAGGGAA, } \\
\text { GGGTTAAAGGAGGCAAATACAG }\end{array}$ & 480 & 0 & 1.8 \\
\hline KRT18 & $\begin{array}{l}\text { TGATAATGC CCGTCTTGCT, } \\
\text { GTGCTCTCCTCAАTCTGCT }\end{array}$ & 375 & 3 & 1.9 \\
\hline$T \cup B B$ & $\begin{array}{l}\text { GAGGCGAGCAAAAAGATTAGA, } \\
\text { CAAGATAGCACGAGGGACA }\end{array}$ & 229 & 2 & 1.9 \\
\hline$Y W H A Q$ & $\begin{array}{l}\text { TGTCCAACGAAGAGCGCAA, } \\
\text { CCGATCATCACCACAAGCAA }\end{array}$ & 308 & 1 & 1.9 \\
\hline SLC16A1 & $\begin{array}{l}\text { ACCAGTTTTAGGTCGTCTCA, } \\
\text { GGCTTCTCAGCAACATCTACA }\end{array}$ & 207 & 1 & 1.9 \\
\hline Cyt c oxi & $\begin{array}{l}\text { CGGAGACGACCAAATCTACAA, } \\
\text { GGAAACTCCTGCTAAGTGTAAA }\end{array}$ & 325 & 0 & 1.8 \\
\hline KRT8 & $\begin{array}{l}\text { GCTACATTAACAACCTCCGTC, } \\
\text { TCATCAGTCAGCCСТTCCA }\end{array}$ & 235 & 2 & 1.9 \\
\hline
\end{tabular}

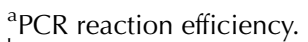

${ }^{\mathrm{b}}$ Cytochrome c oxidase I.

FastStart DNA Master Sybr Green I reaction and enzyme mix (Roche), 4 nmol of each primer, 80 ng MS2 RNA and $2 \mu \mathrm{l}$ template. The thermal programme included a 10 min incubation at $95^{\circ} \mathrm{C}$ to activate the FastStart Taq polymerase followed by 45 cycles of $95^{\circ} \mathrm{C}$ for $10 \mathrm{~s}$, annealing temperature (see Table 1) for $5 \mathrm{~s}$ and $72{ }^{\circ} \mathrm{C}$ for 10-20 s (this varied with amplicon size- 1 s for every 25 base pairs), ramp speed $20^{\circ} \mathrm{C} / \mathrm{s}$. The fluorescence readings were recorded after each $72{ }^{\circ} \mathrm{C}$ step. Dissociation curves were performed after each PCR run to ensure that a single PCR product had been amplified. Products were also analysed by gel electrophoresis and sequencing on first primer pair usage to ensure that the correct gene fragment was amplified. Each blastocyst sample was measured in duplicate per run by using an undiluted and 1:2 diluted aliquot. A no template control of $2 \mu \mathrm{l}$ TE buffer, an RT- control and a standard dilution series were included in each real-time run.

Standard curves were obtained using PCR fragments that were excised from a $1 \%$ agarose gel, purified using a Roche Gel Extraction Kit, resuspended in TE and quantified with both a NanoDrop ND-1000 Spectrophotometer (NanoDrop, Wilmington, DE) and fluorometrically with PicoGreen (Invitrogen) using the LightCycler. Standards consisted of a 10-fold dilution series containing $10^{5}$ to 10 copies/ $\mu$ l. Sample concentrations calculated from the standard curves were converted into an estimate of copy number per blastocyst after correcting for recovery and reverse transcription losses using values obtained for $\alpha$-globin recovery. The average measurement for each blastocyst sample (at least two sample values) was used in statistical analysis of real time PCR results by an unbalanced ANOVA using GenStat (VSN). 


\section{Results}

\section{Experimental strategy}

We here endeavoured to obtain a global picture of the effect of NT on the expression of genes transcribed at the blastocyst stage. To this end we made a novel bovine blastocyst cDNA library allowing the synthesis of a blastocyst-specific microarray. Our bovine day 7 blastocyst cDNA library had a complexity of 1.1 million. The use of oligo-dT mediated reverse transcription ensured inclusion of the $3^{\prime}$ trailers of cDNA isolates, a necessary requisite when hybridising to linearly amplified cDNA which exhibits a similar $3^{\prime}$ bias. Blue/white selection on X-Gal plates showed over $90 \%$ of phages to contain inserts. Amplification of inserts by PCR using vector specific primers yielded an insert size ranging from 0.1 to $5 \mathrm{kbp}$ with a median of $0.7 \mathrm{kbp}$. For the generation of our blastocyst-specific microarray, 5000 insert-containing clones were randomly selected from the primary nonamplified library, PCR amplified and spotted.

A microarray approach necessitated an amplification step to generate sufficient cDNA to hybridise to the arrays, in particular as we wished to examine the expression profile of individual blastocysts, in line with observations that each NT reconstructed embryo exhibits a unique expression profile (CS, DNW, PLP, unpublished observations). We used linear mRNA amplification to achieve this. To assess the degree of bias introduced by this technique, total RNA isolated from two pooled IVP blastocysts was divided equally and both samples concurrently subjected to two rounds of amplification. Comparison of the amplified cDNA after hybridisation to our microarray (Fig. 1A) revealed a strong correlation $(r=0.99)$ between the separate amplifications (Fig. 1B). We conclude that minimal bias was introduced by the linear amplification procedure, yet a small number of false positives are unavoidable.

Genetic effects were minimised by comparing NT embryos to IVP embryos sharing $50 \%$ genetic identity with the NT embryos by virtue of being generated using sperm from the bull from which the skin fibroblast donor cells were derived. The choice to compare NT not to in vivo embryos but rather to IVP embryos cultured in parallel, focused this work on effects specific to the NT procedure as opposed to gene expression differences arising due to embryo culture (Wrenzycki et al. 2005). We attempted to eliminate effects of embryo culture by comparing NT and IVP embryos grown under identical conditions in the same experimental run. Furthermore, all embryos were graded by only one person (DNW) ensuring consistency. For these analyses we used only the top two grades of expanded day 7 blastocysts, representing the grades used for transfers into recipient cows. Such NT embryos derived from fibroblast cells of this particular bull yield blastocyst development rates and implantation/attachment rates equal to IVP embryos,
A

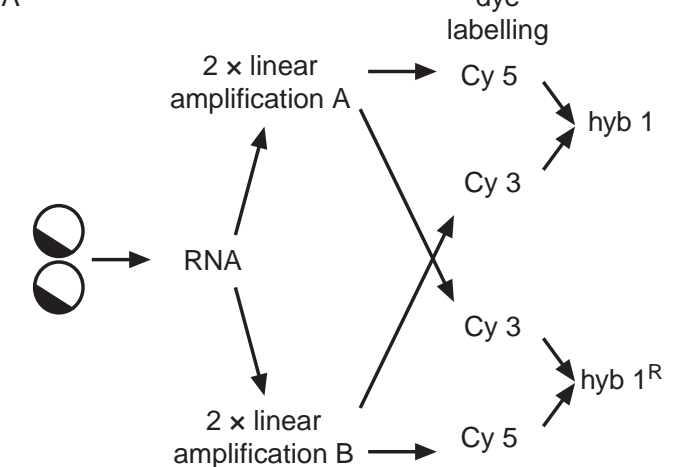

B

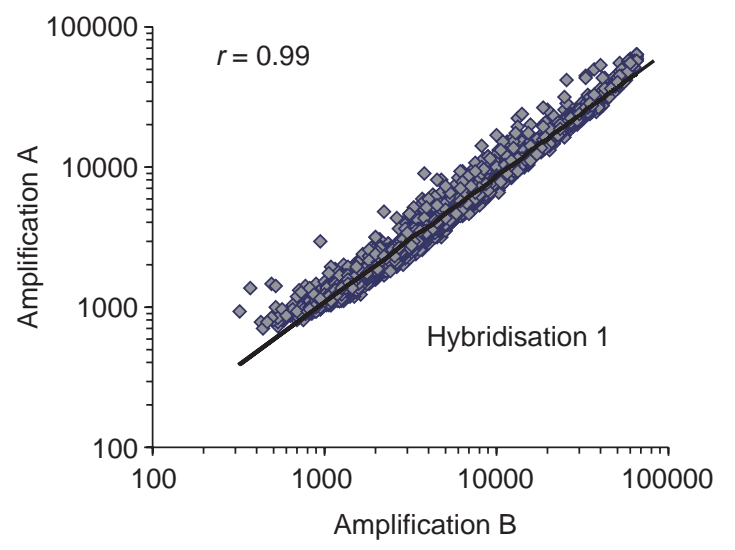

Figure 1 Testing bias resulting from linear amplification. (A) Experimental design for linear amplification bias control testing. RNA derived from 2 blastocysts was split equally and linearly amplified independently (A and B). (B) Plot of the fluorescence intensity generated by hybridising Cy5 labelled amplification $A$ and $C y 3$ labelled amplification B (hyb 1) target to the 5000 features of the blastocystspecific microarray. Note the dye-reversal microarray comparison (Hybridisation $1^{\mathrm{R}}$ ) also displayed a correlation coefficient of $r=0.99$ (not shown).

but, unlike their IVP counterparts, show high mortality rates thereafter (data not shown). Of the six IVP and NT embryos used for linear amplification we discarded two IVP and one NT embryos based on both inadequate amplification efficiency (below $200000 \times$ ) and aberrant gel electrophoretic pattern (strong bias for short fragments). The remaining five NT and four IVP blastocysts were individually hybridised with the reference standard against the microarray. The use of blastocyst cDNA as a reference standard ensured signal generation from all features of our blastocyst-specific microarray.

\section{Microarray results}

Statistical analysis using a spatial mixed model (Baird et al. 2004) identified 164 microarray features (spots) as demonstrating significant differential expression between the means of the NT and IVP blastocysts ( $P \leq 0.05, \geq 1.5$-fold change). Thus of the 5000 features 
examined, $3 \%$ were consistently differentially expressed in the NT blastocysts. Of these features, 121 demonstrated lower expression and 43 higher expression in NT relative to IVP blastocysts. A graphical representation of the mean-adjusted relative expression intensities of each individual blastocyst across the 164 selected features highlights feature variation in individual embryos but also reveals the consistency of differences between the groups of IVP and NT embryos (Fig. 2). In particular, genes normally expressed at the blastocyst stage tend to be expressed at lower levels in NT embryos.

Sequence identification revealed some redundancy among the identified features. Mitochondrial $16 S$ rRNA was detected seven times, a myosin isoform (MYL6) five times, cytochrome $C$ oxidase I four times, keratin 18 (KRT18) and mitochondrial 12S rRNA thrice whereas 12 genes were detected twice (Table 2). The consistent behaviour of these independent duplicates (cDNA isolated from separate phages and thus spotted at different concentrations on the microarray) indicates the reproducibility of the microarray hybridisation procedure. The 121 features expressed at lower levels in NT embryos comprised 92 genes of which 8 (7\%; 9 features as one gene was detected twice) could not be assigned to any known gene homologue. All of the 43 features found at higher levels in NT embryos corresponded to separate genes, though $26(60 \%)$ were unknown.

The differentially expressed genes were classified by function using gene ontology (SOURCE, Stanford University, CA) (Fig. 3). Of the known genes overexpressed in NT blastocysts, those coding for transcription factors and proteins involved in signal transduction and metabolism predominated. Genes expressed at lower levels in NT blastocysts were associated with a large range of gene ontology terms (Fig. 3). Underrepresentation of transcripts in NT derived embryos encoded by the mitochondria (12S and $16 S$ rRNA and cytochrome $C$ oxidase I) were detected multiple times. Other recurrent functions included cytoskeletal (TUBB, TPX2, KRT18, TMSB4X, ACTB, ACTG1, MYL6, TPM4, DIAPH3, VIL2, PHACTR4, EPLIN), protein biosynthesis (EEF1A1, EFG2, BWZ1, EIF5A and ribosomal proteins L4, $L 5, L 21, L 23, L P O, S 4 X, S 7, S 20)$, protein binding/folding (GORASP2, HSPA9B, HSPA5, LGALS3, HAVCR1, CCT4, TCP1) and metabolism/biosynthesis (ADH5, PTGS2, SCP2, ACSL3, NDUFA1, MDH2, IDH3B, OAZ1). The reduced levels of many genes required for the viability of every cell points to a general defect in the NT embryo's cellular machinery.

\section{Real time PCR verification}

Due to the small sample size, the expression levels of a further 17 NT and 16 IVP embryos were measured by the quantitative technique of SYBR-green based real time RT-PCR. As internal housekeeping genes typically used

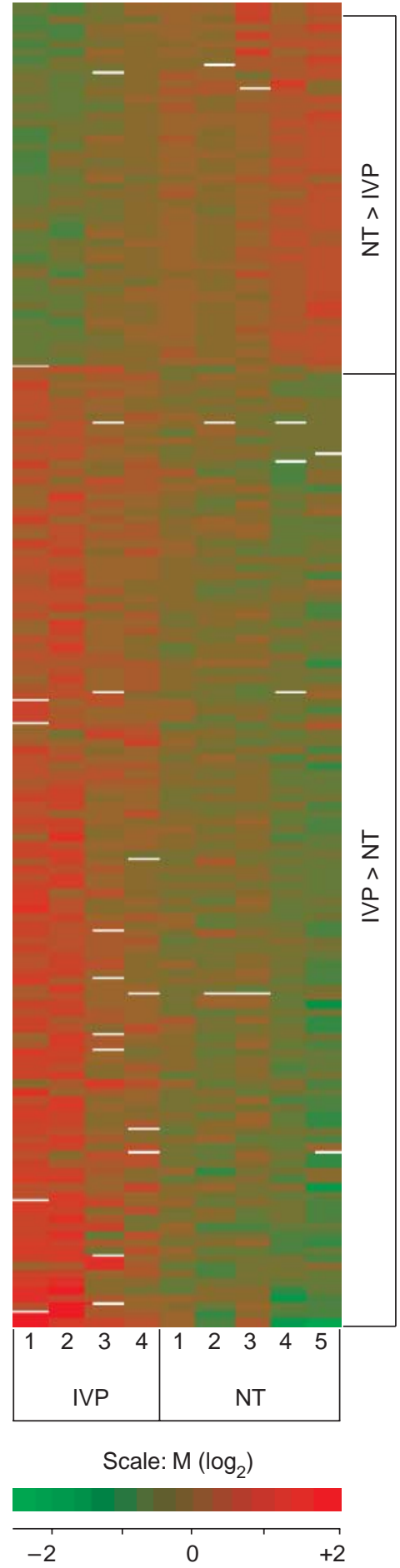

Figure 2 Heat map of the mean adjusted relative expression intensity $\left(\log _{2}[\mathrm{IVP} / \mathrm{NT}]\right)$ of the microarray identified differentially expressed genes ( $P \leq 0.05, \geq 1.5$-fold change). Columns represent individual blastocyst samples, rows represent individual genes. White lines represent absence of a microarray value.

for normalisation may be affected by the NT procedure, we used an exogenous spike of rabbit $\alpha$-globin to adjust for differences in RNA recovery and reverse transcription efficiencies (Donnison \& Pfeffer 2004). All PCR standard 
Table 2 List of genes identified from the microarray analysis as significantly differentially expressed between NT and IVP blastocysts $(P \leq 0.05$, $\geq 1.5$-fold change) $)^{\mathrm{a}}$.

\begin{tabular}{|c|c|c|c|c|c|}
\hline Gene name & $\begin{array}{l}\text { GenBank } \\
\text { accession\# }\end{array}$ & $\begin{array}{c}\text { Fold } \\
\text { change }\end{array}$ & Gene name & $\begin{array}{l}\text { GenBank } \\
\text { accession\# }\end{array}$ & Fold change \\
\hline Expression reduced in clones & & & MYL6 (Myosin) (5x) & NM_175780 & 1.65 \\
\hline TUBB (Beta-tubulin) & XM_600385 & 2.60 & RPL4 (Ribosomal L4) (2x) & NM_001014894 & 1.65 \\
\hline Mitochondrial 12S rRNA (3x) & AY337545 & 2.41 & SNX2 (Sorting nexin 2) (2x) & XM_612796 & 1.65 \\
\hline PTP4A1 (Tyrosine phosphatase) & XM_538984 & 2.35 & BWZ1 (Leucine zipper) & $\begin{array}{l}\text { NM_014038 } \\
\text { BC01779446 }\end{array}$ & 1.64 \\
\hline KRT18 (Cytokeratin 18) (3x) & XM_582930 & 2.28 & HSPA5 (GRP78) & NM_005347 & 1.62 \\
\hline HSPA9B & XM_595707 & 2.26 & DIAPH3 (Diaphanous homologue) & NM_019670 & 1.61 \\
\hline ADH5 (Alcohol dehydrogenase) & XM_581812 & 2.25 & ATP5B (ATP synthase) $\mathbf{( 2 x )}$ & NM_175796 & 1.59 \\
\hline EPLIN & XM_612416 & 2.20 & RPL21 (Ribosomal L21) & XM_588172 & 1.59 \\
\hline UBE2V2 (Ubiquitin conjugating) & NM_003350 & 2.19 & EIF5A (Translation initiation) & XM_580919 & 1.59 \\
\hline EFG2 (Elongation factor) & NM_170691 & 2.16 & IER3IP1 & NM_-016097 & 1.59 \\
\hline SLC7A3 (Transporter) & XM_581045 & 2.14 & RPS20 (Ribosomal S20) & XM_590875 & 1.58 \\
\hline SLC16A1 (Transporter) & XM_582117 & 2.11 & $C K B$ (Creatine kinase) & NM_001015613 & 1.58 \\
\hline TMSB4X (Thymosin, beta) & NM_001002885 & 2.10 & ACTB (Beta actin) & XM_612548 & 1.58 \\
\hline PTGS2 (Prostaglandin synthase) & NM_174445 & 2.08 & RPL23 (Ribosomal L23) & XM_581066 & 1.57 \\
\hline RALY (RNA binding) & NM_001014847 & 2.07 & $Y W H A B$ & NM__174794 & 1.57 \\
\hline GSPT1 (G1 to S phase transition) & NM_146066 & 2.00 & SLC39A1 (Transporter) & NM_001859 & 1.57 \\
\hline TRNT1 & XM_585851 & 1.98 & RCN1 (Reticulocalbin 1) & XM_580691 & 1.57 \\
\hline$A B C B 6$ ( $\mathrm{ABC}$ transporter) & XM_584946 & 1.97 & GORASP2 (Golgi stacking) & NM_-015530 & 1.56 \\
\hline AP2M1 (Adaptor-related complex) & XM_595615 & 1.96 & SLC20A1 (Transporter) & XM_592075 & 1.55 \\
\hline YWHAQ (2x) & XM_582688 & 1.94 & Cytochrome c oxidase I (4x) & AF493542 & 1.55 \\
\hline CDC42 & NM_044472 & 1.94 & RPL5 (Ribosomal L5) & XM_614883 & 1.55 \\
\hline EEF1A1 (Elongation factor) (2x) & XM_600690 & 1.91 & GDI2 (GDP dissociation) & XM_586879 & 1.55 \\
\hline SCP2 (Sterol carrier) & XM_589307 & 1.90 & $\begin{array}{l}\text { H3F3A ( } \mathrm{H} 3 \text { histone, } \\
\text { family } 3 \mathrm{a})\end{array}$ & NM_001014389 & 1.54 \\
\hline HAVCR1 (Cellular receptor) (2x) & XM_585668 & 1.90 & $\begin{array}{l}\text { IDH3B (Isocitrate } \\
\text { dehydrogenase) }\end{array}$ & NM_174856 & 1.54 \\
\hline PHACTR4 & AL840643 & 1.89 & $\begin{array}{l}\text { T1A-2 (Membrane } \\
\text { glycoprotein) }\end{array}$ & XM_586758 & 1.54 \\
\hline LGALS3 (Galectin 3) & XM_588340 & 1.89 & PSMD2 (Proteasome) & XM_589975 & 1.54 \\
\hline ACSL3 (Acyl-CoA synthetase) & NM_203372 & 1.89 & $\begin{array}{l}\text { RPLPO (Ribosome } \\
\text { phosphoprotein) }\end{array}$ & NM_001012682 & 1.53 \\
\hline TEBP (Progesterone receptor) $\mathbf{( 2 \mathbf { x } )}$ & NM_001007806 & 1.87 & C10orf119 & XM_592775 & 1.53 \\
\hline MLP (MARCKS-like protein) & XM_588062 & 1.86 & VIL2 (Villin 2) & NM_174217 & 1.52 \\
\hline ATRX & XM_592333 & 1.85 & TPM4 (Tropomyosin 4) & NM_001001491 & 1.52 \\
\hline RPS7 (Ribosome S7) & XM_581800 & 1.84 & CUL3 (Cullin 3) & NM_003590 & 1.51 \\
\hline NPM1 (Nucleophosmin) (2x) & XM_587109 & 1.84 & NAP1L1 (Nucleosome assembly) & XM_613876 & 1.50 \\
\hline TPX2 (Microtubule associated) & XM_594789 & 1.84 & Unknown (9x) & & \\
\hline PABPC1 (Poly(A) binding) (2x) & NM_174568 & 1.83 & Expression elevated in clones & & \\
\hline OAZ1 (Ornithine antizyme) & XM_583507 & 1.83 & CALM2 (Calmodulin 2) & NM_001009759 & 1.52 \\
\hline CD22 (Antigen) & XM_592455 & 1.82 & PCNA & XM_593532 & 1.52 \\
\hline TCP1 (t-complex chaperone) & XM_589481 & 1.82 & CT120 & XM_585198 & 1.52 \\
\hline BASP1 & NM_174780 & 1.82 & PIP5K2B (Kinase) & XM_592455 & 1.52 \\
\hline Mitochondrial 16S rRNA (7x) & AB099133 & 1.80 & SNX14 (Sorting nexin 14) & XM_532222 & 1.52 \\
\hline PAI-RBP1 (mRNA binding) & XM_584549 & 1.80 & AP3D1 (Adaptor related complex) & NM__173998 & 1.53 \\
\hline TEGT (Bax inhibitor 1) & NM_003217 & 1.79 & RNP24 (Coated vesicle) & XM_588281 & 1.54 \\
\hline SET & XM_580367 & 1.78 & PLAG1 & NM_002655 & 1.54 \\
\hline $\begin{array}{l}\text { NDUFA1 (NADH } \\
\text { dehydrogenase) }\end{array}$ & NM_175794 & 1.78 & GNG5 (G protein) & NM_174811 & 1.56 \\
\hline RRBP1 (Ribosome binding) & NM_001003179 & 1.77 & OAZIN & XM_583507 & 1.59 \\
\hline IL23A (Interleukin) & XM_588269 & 1.76 & NDUFA4 (NADH dehydrogenase) & NM_175820 & 1.59 \\
\hline HNRPA1 (Ribonucleoprotein) (2x) & XM_614145 & 1.75 & DDX24 (DEAD box) & XM_537542 & 1.59 \\
\hline PEX19 (Peroxisome) & NM_002857 & 1.74 & SERTAD1 (SERTA domain) & XM_612612 & 1.59 \\
\hline CCT4 (Chaperonin) & NM_006430 & 1.74 & $\begin{array}{l}\text { IPLA2(GAMMA) } \\
\text { (Phospholipase) }\end{array}$ & XM_613745 & 1.61 \\
\hline ACTG1 (Gamma actin) & XM_612548 & 1.71 & ARHE (Ras homolog) & XM_592424 & 1.67 \\
\hline MAPRE1 (Microtubule associated) & NM_012325 & 1.68 & JJAZ1 (Joined to JAZF1) & XM_582605 & 1.72 \\
\hline$M D H 2(\mathbf{2 x})$ & XM_590742 & 1.67 & KIAA1970 (UBPH) & NM__019116 & 1.79 \\
\hline$R T L F$ (Reverse transcriptase-like) & XM_585472 & 1.67 & Unknown (26x) & & \\
\hline RPS4X (Ribosomal S4) & XM_614302 & 1.66 & & & \\
\hline
\end{tabular}

${ }^{a}$ Some genes were detected more than once and are indicated in bold within parenthesis. Fold change refers to difference in the mean expression of the NT blastocysts relative to the IVP. There are 34 genes that are unknown-2 of the underexpressed unknowns are the same. 


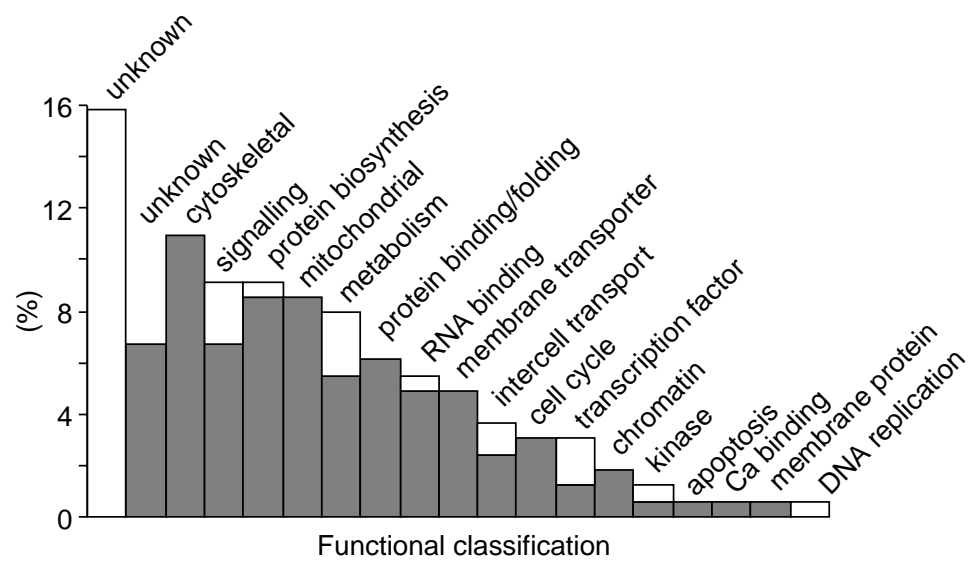

Figure 3 Classification of microarray identified significantly differentially expressed genes into functional categories, with each category expressed as a percentage of the total. Within each category, the fraction of genes which are underexpressed in NT embryos are shaded, those overexpressed are not. curve reaction efficiencies were within $10 \%$ of the ideal amplification efficiency of 2.0 (Table 1). Furthermore, duplicates of all blastocyst samples were measured using a 1:2 dilution to ensure that readings were within the linear range. Quantitative results of 7 downregulated genes are presented (Fig. 4). These included three genes coding for cytoskeletal proteins, namely $\beta$-tubulin 5 (TUBB; highest fold difference in the microarray analysis), KRT18 and MYL6 (detected several times). We also analysed the mitochondrial gene Cytochrome $C$ oxidase I, one of the eight genes coding for ribosomal subunit proteins (RPL21), one of the four genes coding for transporter proteins, (SLC16A1) and one of the signal transduction mediators ( $Y W H A Q)$. We measured GAPDH transcript levels as an internal reference standard allowing comparison with previous quantitative results (CS, DNW and PLP, unpublished observation).

We observed moderate embryo to embryo variation in the expression levels of individual genes in both IVP and NT embryos (Fig. 4). When comparing the mean expression levels between IVP and NT embryos, only two of the seven microarray candidate genes as well as $G A P D H$ exhibited a significant $(P \leq 0.05)$ decrease in transcript levels in NT blastocysts (Table 3). These two genes, KRT18 and the SLC16A1, showed subtle decreases in transcript levels of 1.4- and 1.5-fold respectively. We conclude from these analyses that only a subset of the genes identified as underexpressed in NT embryos by microarray analysis are consistently underexpressed when analysing a larger set of embryos.

We next examined the expression levels of keratin 8 (KRT8), the cytoplasmic partner of KRT18 (Waseem et al. 1990). Interestingly, KRT8 was recently reported as being expressed at lower levels in NT embryos in a microarray study similar to ours (Pfister-Genskow et al. 2005). However, real time quantitation of transcript levels of KRT8 in a set of 16 embryos revealed no significant difference between NT embryos and their half siblings $(P=1.00)$ (Fig. 4, Table 3). It should be noted that both keratin 18 and 8 transcripts are extremely abundant in blastocysts, reaching levels of several hundred thousand copies (Table 3).

\section{Discussion}

\section{The stochastic nature of the gene expression profile differences in individual NT embryos}

During somatic cell nuclear transfer the gene expression profile of the donor cell has to be changed or reprogrammed extensively to reflect that of a normal embryo. Incomplete reprogramming has been proposed to underlie the loss of viability that is known to occur in NT-derived embryos. In our hands and using skin fibroblast donor cells, development to term and beyond of transferred NT embryos is less than 10\% compared to around $40 \%$ for IVP blastocysts (Kruip \& den Daas 1997, Oback et al. 2003, Smeaton et al. 2003, Wells et al. 2003, 2004).

An interesting question regarding incomplete reprogramming concerns the issue of whether particular gene loci are preferentially affected (reprogramming error hotspots) or whether defects are of a stochastic/random global nature. Consistent gene expression changes at a defined set of loci would support the hotspot scenario whereas unpredictability of expression profiles would suggest a stochastic model of reprogramming. Expression profile studies using pools of embryos (Wrenzycki et al. 2001, Donnison \& Pfeffer 2004) are unsuitable for answering this question as stochastic effects are averaged out. Studies of individual NT-generated foetuses or newborns (Humpherys et al. 2001) are severely biased as these animals had already survived many critical phases of embryogenesis during which a large fraction of NT embryos succumb. We thus compared the gene expression of individual NT and 

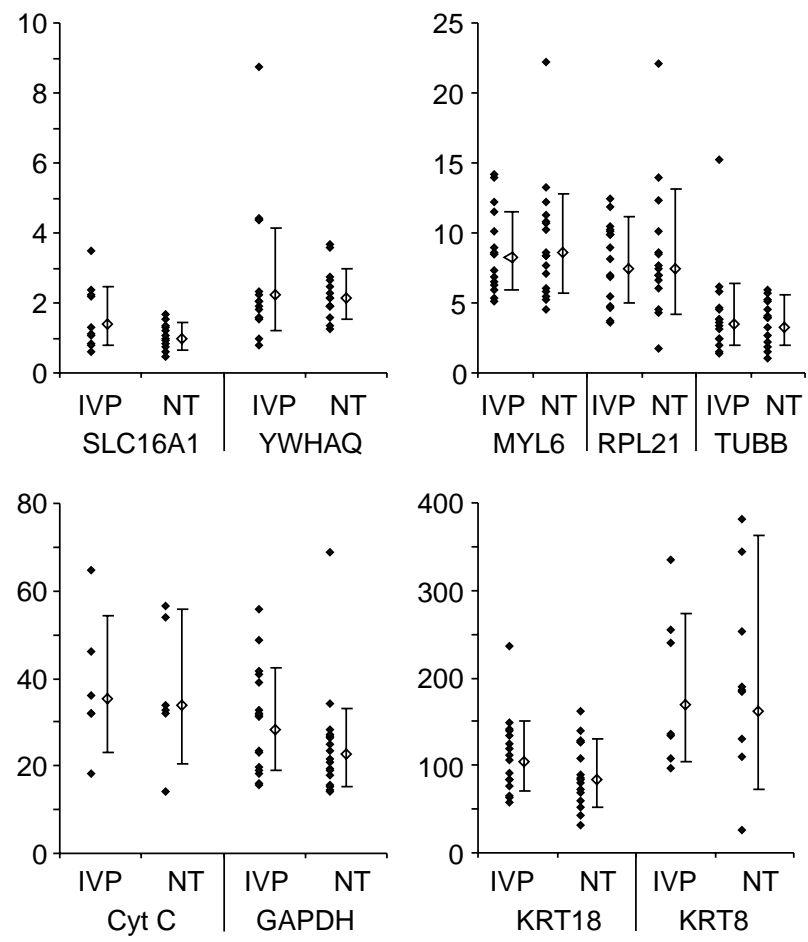

Figure 4 Individual and average gene expression levels (in thousands of transcripts per embryo) in IVP and NT day 7 blastocysts as determined by quantitative real time RT-PCR. Expression in individual blastocysts is represented by diamonds (IVP, $n=16 ; \mathrm{NT}, n=17)$ with the mean and standard deviation (back transformed from log scale) depicted adjacent to each data set. Each individual blastocyst sample was measured twice, once at a 1:2 dilution. Cyt C; cytochrome C oxidase I; KRT, cytokeratin.

genetically half-identical IVP embryos at an early stage (blastocyst) using a global microarray approach. We concentrated on the switching on of embryonic genes by screening a microarray consisting of cDNA derived from a blastocyst library which we constructed for this purpose. Genetic and developmental variation as well as embryo culture effects were minimised in this study.

We identified 92 genes expressed at lower and 43 genes expressed at higher levels in NT embryos $(P<0.05, \geq 1.5$-fold change). The preponderance of underexpressed genes in NT embryos when examining a set of cDNA isolates known to be expressed at the blastocyst stage suggests an impaired capacity of NT embryos for activation of embryo-specific genes. However, a range of functional categories was represented among the identified genes, with a high proportion involved in protein biosynthesis, signalling, cytoskeleton, mitochondrial, protein binding/folding and metabolism/biosynthesis. Most of these genes are not embryo-specific but would be expected to be constitutively active in every cell as they are required for the maintenance of the basal cellular machinery.

Table 3 Mean IVP and NT expression (copy number) \pm s.E.M. for the genes analysed by real time PCR .

\begin{tabular}{lcccc}
\hline & \multicolumn{3}{c}{ Copy number per blastocyst } \\
\cline { 2 - 4 } Genes & IVP Mean \pm S.E.M. & NT Mean \pm S.E.M. & Fold change (IVP/NT) \\
\hline GAPDH & $28300 \pm 2120$ & $21800 \pm 1630$ & 0.02 & 1.3 \\
MYL6 & $8310 \pm 694$ & $8260 \pm 689$ & 0.97 & 1.0 \\
RPL21 & $7460 \pm 854$ & $7120 \pm 815$ & 0.74 & 1.0 \\
KRT18 & $104000 \pm 11200$ & $73900 \pm 7970$ & 0.03 & 1.4 \\
TUBB & $3620 \pm 667$ & $3040 \pm 561$ & 0.52 & 0.86 \\
YWHAQ & $2200 \pm 312$ & $2190 \pm 309$ & 0.04 & 1.2 \\
SLC16A1 & $1240 \pm 179$ & $844 \pm 122$ & 0.87 & 1.5 \\
Cyt C oxi & $28000 \pm 5449$ & $30000 \pm 5840$ & 1.00 & 0.9 \\
KRT8 & $168000 \pm 55400$ & $189000 \pm 62500$ & 0.9 \\
\hline
\end{tabular}

${ }^{\text {a } T h e ~} P$ value represents the statistical difference between the IVP and NT means and the fold change represents the difference of the NT mean relative to the IVP mean.

${ }^{\mathrm{b}}$ Cytochrome c oxidase I. 
Misregulation of these genes in NT embryos therefore points to errors that may not be directly attributable to the donor cell's transcription profile.

It should be pointed out that our results are derived from examining a subset of blastocyst-specific genes. Currently it is believed that about 10000 genes are transcribed in the mammalian blastocyst (Zeng et al. 2004). Based on frequency distributions of expressed sequence tags (ESTs) in non-normalised cDNA libraries (in-house data), we estimate our 5000 randomly chosen microarray features to represent around 1700 different genes. Of these genes we observed $8 \%$ to be consistently $(P<0.05)$ over- or underexpressed by at least 1.5 -fold (none of sample deviated by more than 2.6-fold). Based on this random sample of around 1700 genes the $95 \%$ confidence interval for misexpression of genes after nuclear transfer lies in the range of $6.7-9.4 \%$.

Interestingly, our quantitative data indicated that only a proportion of genes found to be misexpressed in the microarray data set are consistently misregulated when examining a larger set of embryos. On comparing the means of the expression levels of these misregulated genes, the changes seen are small $(<2$-fold). Considering the range of variation detected in the IVP samples, examination of transcript levels of a single gene in individual embryos cannot distinguish an NT from a control embryo. This unpredictability of individual gene expression on a global background of multiple gene expression changes argues for a predominantly stochastic nature of reprogramming errors.

Studies in the mouse can also be interpreted in light of stochastic reprogramming. Thus the expression of Oct4 was found to be independent to that of a transgenic Oct4-enhancer driven reporter gene in individual NT derived blastocysts (Boiani et al. 2002). In a non-quantitative study of 10 putative pluripotency genes in mouse NT embryos, the expression profile was found to differ from embryo to embryo (Bortvin et al. 2003). In the bovine, detailed measurements of transcript levels of a small set of genes in individual embryos has yielded no (Camargo et al. 2005) or only one (CS, DNW, PLP, unpublished data) candidate that is significantly different in a set of IVP and NT embryos. Yet for that candidate, as for GAPDH, KRT18 and SLC16A1 identified in this study, changes in levels are small and, as in the mouse, seen only for a subset of NT embryos. Lastly, the stochastic reprogramming error model would easily account for the observed heterogeneity in the timing and cause of nuclear transfer associated defects: the manifestation of reprogramming errors would be dependent on the particular functions of the random set of genes affected.

\section{Genes expressed at lower levels in NT embryos}

The genes we found here to be more frequently misexpressed in NT embryos were KRT18, SLC16A1 and GAPDH. GAPDH may represent genes whose regulation is influenced by multiple regulatory pathways as it codes for an enzyme implicated in a wide range of cellular processes including glycolysis, tRNA binding, cytoskeleton interaction by the binding of tubulin and microtubules, apoptosis, vesicular transport and telomere length regulation (Sirover 1999, Tisdale 2002, Sundararaj et al. 2004). GAPDH is often used for gene expression normalisation (Bustin 2000, Pfister-Genskow et al. 2005). Our finding illustrates the need for caution in the choice of genes used for normalisation. Exogenous standards circumvent this problem.

The membrane transporter SLC16A1 regulates the uptake of monocarboxylates including pyruvate (Garcia et al. 1994). Pyruvate uptake increases twofold after the expanded blastocyst stage in IVP embryos, suggesting a metabolic requirement for pyruvate at this stage (Rieger et al. 1992). Thus a reduced expression of SLC16A1 in NT embryos may affect their viability. Interestingly our microarray identified reduced mRNA levels for three additional membrane solute carrier transporters, suggesting an altered metabolism in NT blastocysts.

The cytoskeletal keratin proteins KRT18 and KRT8 have been previously detected at early embryonic stages (Chisholm \& Houliston 1987). In the only other global study examining gene expression in individual NT preimplantation embryos using microarrays, KRT8 was found to be underexpressed in clones (Pfister-Genskow et al. 2005). We examined KRT8 expression in our NT embryos using stringent criteria for quantification but found no significant difference in the mean expression levels between our NT and genetically half-identical IVP blastocysts. Though this discrepancy may have arisen from the use of different protocols for NT production and gene quantification in the two studies, it may also simply reflect the stochastic nature of reprogramming errors.

The biological relevance of the multiple small changes in expression is not clear, although it has previously been shown that an increase or decrease of only $50 \%$ in Oct 4 expression induced alternative differentiation pathways in mouse embryonic stem cells (Niwa et al. 2000). As every NT embryo appears to be quite unique in terms of its transcript levels, future studies will have to attempt to correlate gene expression profiles of individual embryos with their subsequent development, a technically daunting task.

\section{Acknowledgements}

We thank Dr Peter Eck for valuable advice on sequencing and Sue Beaumont, Andria Green, Pavla Misica, Fleur Oback, Jan Oliver, Anita Schurmann, Hilda Troskie as well as Drs Debbie Berg and Björn Oback for help with the production of embryos. This work was supported by the New Zealand Foundation for Research, Science and Technology. The authors declare that there is no conflict of interest that would prejudice the impartiality of this scientific work. 


\section{References}

Baird D, Johnstone P \& Wilson T 2004 Normalization of microarray data using a spatial mixed model analysis which includes splines. Bioinformatics 20 3196-3205.

Boiani M, Eckardt S, Scholer HR \& McLaughlin KJ 2002 Oct4 distribution and level in mouse clones: consequences for pluripotency. Genes and Development 16 1209-1219.

Bortvin A, Eggan K, Skaletsky H, Akutsu H, Berry DL, Yanagimachi R, Page DC \& Jaenisch R 2003 Incomplete reactivation of Oct4-related genes in mouse embryos cloned from somatic nuclei. Development 130 1673-1680.

Bourc'his D, Le Bourhis D, Patin D, Niveleau A, Comizzoli P, Renard JP \& Viegas-Pequignot E 2001 Delayed and incomplete reprogramming of chromosome methylation patterns in bovine cloned embryos. Current Biology 11 1542-1546.

Bustin SA 2000 Absolute quantification of mRNA using real-time reverse transcription polymerase chain reaction assays. Journal of Molecular Endocrinology 25 169-193.

Camargo LS, Powell AM, Filho VR \& Wall RJ 2005 Comparison of gene expression in individual preimplantation bovine embryos produced by in vitro fertilisation or somatic cell nuclear transfer. Reproduction, Fertility and Development 17 487-496.

Chisholm JC \& Houliston E 1987 Cytokeratin filament assembly in the preimplantation mouse embryo. Development 101 565-582.

Daniels R, Hall V \& Trounson AO 2000 Analysis of gene transcription in bovine nuclear transfer embryos reconstructed with granulosa cell nuclei. Biology of Reproduction 63 1034-1040.

Daniels R, Hall VJ, French AJ, Korfiatis NA \& Trounson AO 2001 Comparison of gene transcription in cloned bovine embryos produced by different nuclear transfer techniques. Molecular Reproduction and Development 60 281-288.

De Sousa PA, King T, Harkness L, Young LE, Walker SK \& Wilmut I 2001 Evaluation of gestational deficiencies in cloned sheep fetuses and placentae. Biology of Reproduction 65 23-30.

Dean W, Santos F, Stojkovic M, Zakhartchenko V, Walter J, Wolf E \& Reik W 2001 Conservation of methylation reprogramming in mammalian development: aberrant reprogramming in cloned embryos. PNAS 98 13734-13738.

Diez-Tascón C, Keane OM, Wilson T, Zadissa A, Hyndman DL, Baird DB, McEwan JC \& Crawford AM 2005 Microarray analysis of selection lines from outbred populations to identify genes involved with nematode parasite resistance in sheep. Physiological Genomics 21 59-69.

Donnison M \& Pfeffer PL 2004 Isolation of genes associated with developmentally competent bovine oocytes and quantitation of their levels during development. Biology of Reproduction 71 1813-1821.

Eck P, Erichsen HC, Taylor JG, Yeager M, Hughes AL, Levine M \& Chanock S 2004 Comparison of the genomic structure and variation in the two human sodium-dependent vitamin $\mathrm{C}$ transporters, SLC23A1 and SLC23A2. Human Genetics 115 285-294.

Gao S, Chung YG, Williams JW, Riley J, Moley K \& Latham KE 2003 Somatic cell-like features of cloned mouse embryos prepared with cultured myoblast nuclei. Biology of Reproduction 69 48-56.

Garcia CK, Goldstein JL, Pathak RK, Anderson RG \& Brown MS 1994 Molecular characterization of a membrane transporter for lactate, pyruvate, and other monocarboxylates: implications for the Cori cycle. Cell 76 865-873.

Gibbons J, Arat S, Rzucidlo J, Miyoshi K, Waltenburg R, Respess D, Venable A \& Stice S 2002 Enhanced survivability of cloned calves derived from roscovitine-treated adult somatic cells. Biology of Reproduction 66 895-900.

Hill JR, Burghardt RC, Jones K, Long CR, Looney CR, Shin T, Spencer TE, Thompson JA, Winger QA \& Westhusin ME 2000 Evidence for placental abnormality as the major cause of mortality in first-trimester somatic cell cloned bovine fetuses. Biology of Reproduction 63 1787-1794.

Hochedlinger K \& Jaenisch R 2002 Nuclear transplantation: lessons from frogs and mice. Current Opinion in Cell Biology 14 741-748.
Humpherys D, Eggan K, Akutsu H, Hochedlinger K, Rideout WM 3rd, Biniszkiewicz D, Yanagimachi R \& Jaenisch R 2001 Epigenetic instability in ES cells and cloned mice. Science 293 95-97.

Kang YK, Koo DB, Park JS, Choi YH, Chung AS, Lee KK \& Han YM 2001 Aberrant methylation of donor genome in cloned bovine embryos. Nature Genetics 28 173-177.

Kang YK, Park JS, Koo DB, Choi YH, Kim SU, Lee KK \& Han YM 2002 Limited demethylation leaves mosaic-type methylation states in cloned bovine pre-implantation embryos. Embo J 21 1092-1100.

Kruip TAM \& den Daas JHG 1997 In vitro produced and cloned embryos: effects on pregnancy, parturition and offspring. Theriogenology $4743-52$.

Lanza RP, Cibelli JB, Faber D, Sweeney RW, Henderson B, Nevala W, West MD \& Wettstein PJ 2001 Cloned cattle can be healthy and normal. Science 294 1893-1894.

Niwa H, Miyazaki J \& Smith AG 2000 Quantitative expression of Oct$3 / 4$ defines differentiation, dedifferentiation or self-renewal of ES cells. Nature Genetics 24 372-376.

Oback B, Wiersema AT, Gaynor P, Laible G, Tucker FC, Oliver JE, Miller AL, Troskie HE, Wilson KL, Forsyth JT et al. 2003 Cloned cattle derived from a novel zona-free embryo reconstruction system. Cloning Stem Cells 5 3-12.

Ogonuki N, Inoue K, Yamamoto Y, Noguchi Y, Tanemura K, Suzuki O, Nakayama H, Doi K, Ohtomo Y, Satoh M et al. 2002 Early death of mice cloned from somatic cells. Nature Genetics 30 253-254.

Ogura A, Inoue K, Ogonuki N, Lee J, Kohda T \& Ishino F 2002 Phenotypic effects of somatic cell cloning in the mouse. Cloning Stem Cells 4 397-405.

Pace MM, Augenstein ML, Betthauser JM, Childs LA, Eilertsen KJ, Enos JM, Forsberg EJ, Golueke PJ, Graber DF, Kemper JC et al. 2002 Ontogeny of cloned cattle to lactation. Biology of Reproduction $\mathbf{6 7}$ 334-339.

Park SH, Park SB \& Kim NH 2003 Expression of early developmentrelated genes in bovine nuclear transferred and fertilized embryos. Zygote 11 355-360.

Pfister-Genskow M, Myers C, Childs LA, Lacson JC, Patterson T, Betthauser JM, Goueleke PJ, Koppang RW, Lange G, Fisher P et al. 2005 Identification of differentially expressed genes in individual bovine preimplantation embryos produced by nuclear transfer: improper reprogramming of genes required for development. Biology of Reproduction 72 546-555.

Rhind SM, King TJ, Harkness LM, Bellamy C, Wallace W, de Sousa P \& Wilmut I 2003 Cloned lambs - lessons from pathology. Nature Biotechnology 21 744-745.

Rieger D, Loskutoff NM \& Betteridge KJ 1992 Developmentally related changes in the uptake and metabolism of glucose, glutamine and pyruvate by cattle embryos produced in vitro. Reproduction, Fertility and Development 4 547-557.

Robertson I \& Nelson R 1998 Certification and identification of the embryo. In Manual of the International Embryo Transfer Society, pp 103-134. Eds AD Stringfellow \& SM Seidel. Illinois: International Embryo Transfer Society.

Santos F, Zakhartchenko V, Stojkovic M, Peters A, Jenuwein T, Wolf E, Reik W \& Dean W 2003 Epigenetic marking correlates with developmental potential in cloned bovine preimplantation embryos. Current Biology 13 1116-1121.

Shimozawa N, Ono Y, Kimoto S, Hioki K, Araki Y, Shinkai Y, Kono T \& Ito $\mathbf{M} 2002$ Abnormalities in cloned mice are not transmitted to the progeny. Genesis 34 203-207.

Sirover MA 1999 New insights into an old protein: the functional diversity of mammalian glyceraldehyde-3-phosphate dehydrogenase. Biochimica et Biophysica Acta 1432 159-184.

Smeaton DC, McGowan LT, Scott ML, Tervit HR \& Cameron CA 2003 Survival of in vitro produced cattle embryos from embryo transfer to weaning. Proceedings of the New Zealand Society of Animal Production 63 57-60.

Sundararaj KP, Wood RE, Ponnusamy S, Salas AM, Szulc Z, Bielawska A, Obeid LM, Hannun YA \& Ogretmen B 2004 Rapid shortening of 
telomere length in response to ceramide involves the inhibition of telomere binding activity of nuclear glyceraldehyde-3-phosphate dehydrogenase. Journal of Biological Chemistry 279 6152-6162.

Tamashiro KL, Wakayama T, Akutsu H, Yamazaki Y, Lachey JL, Wortman MD, Seeley RJ, D'Alessio DA, Woods SC, Yanagimachi R et al. 2002 Cloned mice have an obese phenotype not transmitted to their offspring. Nature Medicine 8 262-267.

Thompson JG, McNaughton C, Gasparrini B, McGowan LT \& Tervit HR 2000 Effect of inhibitors and uncouplers of oxidative phosphorylation during compaction and blastulation of bovine embryos cultured in vitro. Journal of Reproduction and Fertility 118 47-55.

Tisdale EJ 2002 Glyceraldehyde-3-phosphate dehydrogenase is phosphorylated by protein kinase Ciota /lambda and plays a role in microtubule dynamics in the early secretory pathway. Journal of Biological Chemistry 277 3334-3341.

Wang E, Miller LD, Ohnmacht GA, Liu ET \& Marincola FM 2000 Highfidelity mRNA amplification for gene profiling. Nature Biotechnology 18 457-459.

Waseem A, Alexander CM, Steel JB \& Lane EB 1990 Embryonic simple epithelial keratins 8 and 18: chromosomal location emphasizes difference from other keratin pairs. New Biologist 2 464-478.

Wells DN, Forsyth JT, McMillan V \& Oback B 2004 The health of somatic cell cloned cattle and their offspring. Cloning Stem Cells 6 101-110.

Wells DN, Laible G, Tucker FC, Miller AL, Oliver JE, Xiang T, Forsyth JT, Berg MC, Cockrem K, L'Huillier PJ et al. 2003 Coordination between donor cell type and cell cycle stage improves nuclear cloning efficiency in cattle. Theriogenology 59 45-59.

Wells DN, Misica PM, Day TA \& Tervit HR 1997 Production of cloned lambs from an established embryonic cell line: a comparison between in vivo- and in vitro-matured cytoplasts. Biology of Reproduction 57 385-393.
Wilmut I, Beaujean N, de Sousa P, Dinnyes A, King TJ, Paterson LA, Wells DN \& Young LE 2002 Somatic cell nuclear transfer. Nature 419 583-586.

Wrenzycki C, Herrmann D, Lucas-Hahn A, Korsawe K, Lemme E \& Niemann H 2005 Messenger RNA expression patterns in bovine embryos derived from in vitro procedures and their implications for development. Reproduction, Fertility and Development 17 23-35.

Wrenzycki C, Wells D, Herrmann D, Miller A, Oliver J, Tervit R \& Niemann H 2001 Nuclear transfer protocol affects messenger RNA expression patterns in cloned bovine blastocysts. Biology of Reproduction 65 309-317.

Zakhartchenko V, Alberio R, Stojkovic M, Prelle K, Schernthaner W, Stojkovic P, Wenigerkind H, Wanke R, Duchler M, Steinborn R et al. 1999 Adult cloning in cattle: potential of nuclei from a permanent cell line and from primary cultures. Molecular Reproduction and Development 54 264-272.

Zakhartchenko V, Mueller S, Alberio R, Schernthaner W, Stojkovic M, Wenigerkind H, Wanke R, Lassnig C, Mueller M, Wolf E et al. 2001 Nuclear transfer in cattle with non-transfected and transfected fetal or cloned transgenic fetal and postnatal fibroblasts. Molecular Reproduction and Development 60 362-369.

Zeng F, Baldwin DA \& Schultz RM 2004 Transcript profiling during preimplantation mouse development. Developmental Biology 272 483-496.

Received 16 September 2005

First decision 21 October 2005

Revised manuscript received 26 October 2005

Accepted 27 February 2006 